\title{
The Effects of Using Kahoot! on Understanding the Concept of Mathematical Symbols in Higher Education
}

\author{
Molli Wahyuni', Mohammad Fauziddin², Lussy Midani Rizki3
}

DOI: 10.35445/alishlah.v13i3.971

\section{Article Info}

Keywords: Understanding concept; Kahoot!; Math Symbols

Kata kunci:

Pemahaman konsep;

Kahoot!;

Simbol matematika

\begin{abstract}
This research was motivated by the condition of Mathematics Education students who were unfamiliar and unable to read and use these mathematical symbols correctly. This study aimed to examine the effect of Kahoot! game media on students' understanding of concepts, especially on mathematical symbols. The population of this study was students of the Mathematics Education Study Program at Pahlawan Tuanku Tambusai University. At the same time, the research sample was 100 people obtained through random sampling, namely students who attended the introduction of mathematical symbols. The data was collected by taking a mathematical understanding test before and after using the Kahoot game media. Analysis of the data used was the paired t-test. The results showed a difference in the pre-test and post-test scores of students' conceptual understanding, where the significance value was $<0.05 \%$.
\end{abstract}

\begin{abstract}
Abstrak
Penelitian ini dilatarbelakangi atas kondisi memperihatinkan dimana masih banyak mahasiswa Pendidikan Matematika yang belum familiar dengan simbolsimbol matematika sehingga tidak mampu membaca dan menggunakan simbolsimbol matematika tersebut dengan baik. Tujuan penelitian ini adalah untuk menguji pengaruh media game kahoot! pada pemahaman konsep mahasiswa khususnya terhadap simbol-simbol matematika. Pengumpulan data dilakukan dengan pengambilan test pemahaman matematika sebelum dan sesudah menggunakan media game kahoot. Populasi penelitian ini adalah mahasiswa Prodi Pendidikan Matematika Universitas Pahlawan Tuanku Tambusai, sedangkan sampel penelitian sebanyak 100 orang yang diperoleh melalui insidental sampling, yakni mahasiswa yang menghadiri kegiatan pengenalan simbol-simbol matematika. Analisis data yang digunakan yaitu uji sampel berpasangan paired t-test. Hasil penelitian menunjukkan bahwa terdapat perbedaan signifikan skor pre-test dan post-test pemahaman konsep mahasiswa, dimana nilai signifikansi<0,05\%.
\end{abstract}

\footnotetext{
${ }^{1}$ Universitas Pahlawan Tuanku Tambusai, Riau, Indonesia Email: whykpr@gmail.com

${ }^{2}$ Universitas Pahlawan Tuanku Tambusai, Riau, Indonesia Email: mfauziddin@gmail.com

${ }^{3}$ Universitas Pahlawan Tuanku Tambusai, Riau, Indonesia Email: lussymidani@gmail.com
} 


\section{INTRODUCTION}

The understanding mathematical concept is one of the mathematical abilities that are expected to be mastered by students. It plays a role in facilitating students to derive formulas and solve mathematical problems (Arifiyanti, F., Djudin T., dan Haratua, 2013). Understanding mathematical concepts will make it easier for students to solve problems without memorizing the formulas that will be used (Sheftyawan et al., 2018). Hiebert, J. \& Carpenter (1992) interpreted mathematical understanding as one of the main ideas that are the basis of thinking in all levels of mathematics education. In other words, students must understand the mathematical concept first.

The importance of understanding mathematical concepts was also stated by Piere \& Kieren (1994), who mentions that interest in learning mathematics in terms of understanding was shown in recent curricular reforms in many countries (Pirie \& Kieren, 1994). This interest was also reflected in conference proceedings and research articles in psychology and artificial intelligence. According to Pirie \& Kieren (1994) and (Koyama 1993), the notion of understanding is characterized into several aspects, such as increasing the understanding of concepts and identifying the pedagogical actions that support it and how sustainable that understanding is. Midgett \& Eddins (2001) said that students' understanding of mathematical concepts is illustrated by several things, such as (1) defining concepts verbally and in writing; (2) identifying examples and nonexamples; (3) using models, diagrams, and symbols to present a concept; (4) changing one form of presentation into another form; (5) recognizing various meanings and interpretations of concepts; (6) identifying the characteristics of a concept and recognizing the conditions that determine a concept; (7) comparing and contrasting the concepts.

Identically, mathematics is synonymous with various symbols that must be understood and used in solving problems. Understanding the concept of mathematical symbols is very important for students to not have misconceptions in studying advanced mathematics material in college. Symbols are one of the greatest strengths of mathematics (Midgett \& Eddins, 2001). Most students have not been able to optimally interpret different symbols (Baroody \& Ginsburg, 1983; Kieran, 1981; McNeil \& Alibali, 2005; (Rittle-Johnson \& Alibali, 1999) so that it causes students to have difficulty in solving math problems (Powell et al., 2015; Powell \& Fuchs, 2010; Cobb et al., 2000).

Based on the results of the pilot study carried out at the Mathematics Education Study Program at Pahlawan Tuanku Tambusai University, many students still do not know mathematical symbols and have not been able to read and have not been able to use them. Most of the students only know the primary symbols of mathematics that were also known before at the secondary education level. However, for symbols that are more specific and used in advanced mathematics, students still have difficulty. Here are some examples of mathematical symbols.

Table 1. Some Examples of Mathematical Symbols

\begin{tabular}{|c|c|c|c|c|}
\hline Symbol & Concept & First User & Year & Books/Articles/Manuscripts \\
\hline$“ \square ”$ & sum of series & Euler & 1755 & $\begin{array}{l}\text { Institutiones calculi } \\
\text { differential }\end{array}$ \\
\hline “ $\square ”$ & $\begin{array}{l}\text { multiplication of } \\
\text { series }\end{array}$ & Gauss & 1812 & - \\
\hline “| |" & absolute value & William Oughtred & 1631 & Clavis Mathematicae \\
\hline “--->” & $\begin{array}{l}\text { mapping the } \\
\text { element }\end{array}$ & Oystein Ore & 1936 & dalam L Agebre Abstraite \\
\hline "f :X-->Y" & mapping the & Hurewich & Nop & makalah Hurewich-Steenrod \\
\hline “口” & function & Pierre Hérigone & $\begin{array}{l}1941 \\
1634\end{array}$ & Cursus mathematicus \\
\hline “ $\square ”$ & triangle & Heron (m.k.62) & 150 & - \\
\hline “ $\square ”$ & similar & Leibniz & 1679 & sebuah manuskrip \\
\hline “ $\square ”$ & congruent & $\begin{array}{l}\text { Mollweide (1774- } \\
\text { 1825) }\end{array}$ & 1824 & Euklid's Elemente \\
\hline
\end{tabular}




\begin{tabular}{|c|c|c|c|c|}
\hline " $m "$ & gradient & $\begin{array}{l}\text { Vicenzo Riccati } \\
(1676-1754)\end{array}$ & 1757 & $\begin{array}{l}\text { De method Hermanni ad lo- } \\
\text { cos geometricos resolvendos }\end{array}$ \\
\hline “||” & parallel & John Kersey & 1673 & Algebra \\
\hline “ $\square ”$ & perpendicular & Pierre Hérigone & 1634 & Cursus mathematicus \\
\hline
\end{tabular}

Source : (Sumardyono, 2012)

The lack of students' understanding of mathematical concepts is one of the causes of mathematical problems error. Hoban (2019) also commented that it is essential to understand mathematics (and we believe this necessarily includes the reading and writing of mathematics) rather than the ability to apply mathematics to chemistry. (Bardini \& Pierce, 2015) anticipates that some students are familiar with symbols commonly used by university lecturers but have difficulty finding new symbols, so it shows that students do not understand the mathematical content with the new concept. It is difficult to understand the new material.

Mathematizing can be seen when someone uses mathematical symbols to describe and analyze between objects in a situation and the object's actions. For example, seven birds are sitting on the roof and suddenly two birds come close. Van Oers said that mathematization occurs by paying attention to several things, such as the object in the event, namely birds, mathematical objects in the form of the number of birds before other birds joined, as well as the number of birds that came, and the process of adding birds which is an addition action, which is symbolized by the addition operation. (+) so that it is known that in the case of the bird, addition applies. Van Oers revealed that a student in mathematics must be able to explore and mathematize an event using various relevant mathematical symbols, and finally, the student is able to introduce the symbol to others. The process of mathematization and symbolization proposed by Van Oers is a semiotic activity similar to literacy activities currently being promoted (Cobb et al., 2000). Mathematics, which is generally considered a complex subject, is expected to be taught in a fun way, so the game is one of the efforts to increase students' visuality to create fun mathematics learning(Arindiono \& Ramadhani, 2013).

In the era of information technology, various media can improve students' understanding of mathematical concepts, including games, video, audio, and other media. Generally, games are considered a medium for entertainment, but games can be used for exciting learning media, so that in recent times researchers have increasingly developed educational games (Wulandari et al., 2017; Karyanti \& Komarudin, 2017). One of the games that can be used is Kahoot!, an interactive game to attract students' interest in competing to express answers to the questions given. Wang \& Tahir (2020) Mathematics, which is generally considered a complex subject, is expected to be taught in a fun way, so the game is one of the efforts to increase students' visuality to create fun mathematics learning (Sharples, 2000). Kahoot facilitates teachers to create content easily, giving quizzes on learning materials to assess students' comprehension skills. The students do not have to go through the registration process to join this game, and the learning atmosphere is more cheerful because it spurs students to compete in the allotted time, moreover who is the winner can be known directly in this game (Wang, 2015).

Kahoot! is a game or media for testing a game-based tool resulting from a Lecture Quiz research project started in $\mathbf{2 0 0 6}$ at the Norwegian University of Science and Technology (NTNU). The results of an early prototype experiment showed positive results in increased engagement, motivation, and perception of learning (Lin \& Chen, 2017; Wang \& Lieberoth, 2016). Kahoot is a game-based learning platform initially only used as a technology in education, both in schools and other educational institutions. However, Kahoot is a game tool that can sharpen the brain to help students understand the subject matter, increase engagement and motivation, students are more focused, and provide effective and reflective feedback. (Ismail \& Mohammad, 2017; Ulimaz \& Agustina, 2020).

This study was conducted to examine the effect of using Kahoot! game media on the understanding of mathematical concepts in mathematical symbols of mathematics education 
students. The use of the Kahoot game media is expected to provide color in honing students' abilities in understanding more mathematical symbols, especially symbols that are often used in advanced mathematics material.

\section{METHODS}

This research is quantitative research, by carrying out experiments for one group sample. The research population was the students of the Mathematics Education Study Program at Pahlawan Tuanku Tambusai University. The sampling technique used was random sampling. The sample were students attending the mathematical symbol literacy seminar of Mathematics Education Study Program Pahlawan Tuanku Tambusai University. The research sample was 100 people obtained through random sampling, namely students who introduced mathematical symbols.

Table 2. Research design

\begin{tabular}{ccc}
\hline Pre Test & Treatment & Post Test \\
\hline O1 & $\mathrm{X}$ & $\mathrm{O} 2$ \\
\hline
\end{tabular}

Notations:

$\mathrm{O}_{1} \quad=$ Pre-test was given to students

$\mathrm{X}=$ use of Kahoot game media

$\mathrm{O}_{2} \quad=$ Post-test was given to students

For assessing students' understanding of mathematical symbols, a score of zero was given for the wrong answer, and a score of 1 was given for the correct answer. Analysis of the research data using Mc Nemar's test or non-parametric comparative test. Data processing was carried out using SPSS Version 25.00.

\section{FINDINGS AND DISCUSSION}

The score was taken twice, namely in the pre-test and post-test, using the Kahoot game. After taking the pre-test scores, students were explained the mathematical symbols and trained to answer the Kahoot! game for three times. After completing the provision of materials and exercises, the post-test scores were taken.

A pre-test was carried out to determine the students' initial understanding of various mathematical symbols. One hundred students were given 30 questions within 45 minutes to answer the meaning of mathematical symbols. The score for correct answers is 1, and the score for incorrect answers is 0 . The questions given include presenting representations of mathematical symbols in the fields of basic symbols of mathematics, geometry, algebra, sets, statistics, logic, and calculus. In addition, the questions given were also mainly in the form of formulas that use more mathematical symbols. The following are the results of students' answers about mathematical symbols at the pre-test stage.

\begin{tabular}{|c|c|}
\hline Answer & Total student \\
\hline $\begin{array}{c}\text { Correct } \\
\text { Incorrect }\end{array}$ & $\begin{array}{l}37 \\
63\end{array}$ \\
\hline
\end{tabular}

The number of students who answered correctly was 37 people, and the number of students who answered incorrectly was 63 people. The number of students with mathematical symbols was still relatively small because less than 50 percent answered correctly. Most of the students said they did not know some of the symbols proposed in the problem, so they did not understand and could not even discuss how to read the symbols.

Then, to facilitate understanding to students, an exercise to recognize mathematical symbols was carried out using Kahoot! game, and students who achieved the highest score were rewarded in the form of door prizes. In the use of the Kahoot game, each symbol has an alternative answer. Students are very excited because the games given are pretty challenging with a specific time limit 
for each question, and they get the opportunity to see alternative answers. The learning atmosphere was fun, and students seemed happy to follow the process of understanding mathematical symbols using the Kahoot game media. After introducing symbols using the Kahoot game twice, students were again tested to answer the same questions as the pre-test. The following are the results of student answers at the post-test stage.

\section{Table 4. Post-Test Score of Understanding of Mathematics Symbol}

\begin{tabular}{cc}
\hline Answer & Total student \\
\hline Correct & 70 \\
Incorrect & 30 \\
\hline
\end{tabular}

The post-test results showed that students' understanding of mathematical symbols after learning with Kahoot game media was better, marked by an increase in the number of students who answered correctly. Furthermore, to see the significance of differences in students' understanding of mathematical symbol concepts, McNemar's non-parametric comparative test was used using the SPSS Version 25.00 application. The results of the comparative test output can be seen in the following Table 5 .

Table 5. Mc Nemar. Non-Parametric Statistical Test
Results

\section{a. McNemar Test} .000

\section{b. Continuity Corrected}

Based on the output results, it is known that the Asymp Sig value is $0.000<$ alpha (0.05), it can be concluded that there is a significant difference between the pre-test and post-test scores of students' understanding of mathematical symbols concept. In other words, the use of Kahoot game media has a significant effect on increasing the ability to understand mathematical symbols for students of the Mathematics Education Study Program at Pahlawan Tuanku Tambusai University.

Kahoot! has a significant effect on increasing the ability to understand mathematical concepts, which focuses on understanding mathematical symbols in this study. Many students can answer the questions given after being introduced to mathematical symbols using Kahoot! Game media. The same study results were also found (Wigati, 2019) that there is an increase in student learning outcomes after using Kahoot! Game media. The Kahoot game can be operated easily because it can be implemented using Android and only needs a stable internet network. Kahoot! is one of the efforts to make fun of learning and condition the class more effectively, same as research conducted by Khabidin (2019), which stated that there is a difference in conditioning the class with the game Kahoot. Wang \& Tahir (2020) completed a literature review of 93 studies and concluded that Kahoot! positively affects learning performance, classroom dynamics, student and teacher attitudes, and student anxiety. The research results by Sartika \& Octafiani (2019) showed that Kahoot! is very suitable to be used as an evaluation tool. It is because of the Kahoot! improves the learning to be more exciting and also increases the student creativity and activity. Kahoot is an online application where we can create quizzes and present them in games, while students can see the points given for correct answers directly. Game-based learning can be an effective tool because it stimulates visual and verbal components (Iwamoto et al., 2017).

\section{CONCLUSION}

The use of games is one solution that can improve understanding mathematical concepts, especially in understanding mathematical symbols. Through games, students can learn to be more 
relaxed so that they feel fun learning mathematics. The Kahoot game used in this study was used to measure the ability to understand mathematical concepts by modifying the questions presented in the game. This game is also used as a tool for the training process. Students are more accustomed to understanding concepts at varying times, according to the level of difficulty of the questions given. Understanding mathematical concepts, especially for students' mathematical symbols, has a significant difference before and after using the Kahoot game media. This result is evidenced by Mc Nemar's non-parametric test of pre-test and post-test scores of students' answers, where the asymp. Value of sig <0.05. The significant difference in pre-test and post-test scores strengthens the results of descriptive statistics, which show that more students answered correctly in the posttest than in the pre-test.

\section{REFERENCES}

Arifiyanti, F., Djudin T., dan Haratua, T. M. S. (2013). Penggunaan model. 2(10), 1-9.

Arindiono, R. Y., \& Ramadhani, N. (2013). Perancangan Media Pembelajaran Interaktif Matematika untuk Siswa Kelas 5 SD. Jurnal Sains Dan Seni Pomits, 2(1), 28-32. ejurnal.its.ac.id/index.php/sains_seni/article/view/2856\%oD

Bardini, C., \& Pierce, R. (2015). Assumed Mathematics Knowledge: the Challenge of Symbols. International Journal of Innovation in Science and Mathematics Education, 23.

Baroody, A. J., \& Ginsburg, H. P. (1983). The Effects of Instruction on Children's Understanding of the "Equals" Sign. The Elementary School Journal, 84(2), 199-212. https://doi.org/10.1086/461356

Cobb, D. P., Yackel, E., Editors, K. M., \& Erlbaum, N. J. L. (2000). Book Review: 693-702.

Hiebert, J. \& Carpenter, T. P. (1992). Learning and teaching with understanding. MacMilan. https://files.eric.ed.gov/fulltext/ED373971.pdf

Hoban, R. A. (2019). A resource for introducing students to the integral concept. International Journal of Mathematical Education in Science and Technology, 5o(4), 603-616. https://doi.org/10.1080/0020739X.2018.1480809

Ismail, M. A.-A., \& Mohammad, J. A.-M. (2017). Kahoot: A Promising Tool for Formative Assessment in Medical Education. Education in Medicine Journal, 9(2), 19-26. https://doi.org/10.21315/eimj2017.9.2.2

Iwamoto, D. H., Hargis, J., Taitano, E. J., \& Vuong, K. (2017). Analyzing the efficacy of the testing effect using Kahoot ${ }^{\mathrm{TM}}$ on student performance. Turkish Online Journal of Distance Education, 18(2), 80-93. https://doi.org/10.17718/tojde.306561

Karyanti, \& Komarudin. (2017). Pengaruh Model Pembelajaran Kumon Terhadap Peserta Didik Pada Mata Pelajaran Matematika. Prosising Seminar Nasional Matematika Dan Pendidikan Matematika, 1, 89-94.

Khabidin. (2019). Efektifitas Penerapan Aplikasi Kahoot Dalam Mengkondisikan Kelas Pada Mata Pelajaran Pendidikan Agama Islam Di Smp N 1 Pagentan Kabupaten Banjarnegara. 150.

Kieran, C. (1981). Preschoolers 'acquisition of the ability to count two distinct sets is generally followed by the acquisition of the ability to put together two distinct sets and to count the number of elements in their " union" ( Brush , 1978 ; Fuson , 1979; Gelman \& . 12, 317-326.

Koyama, M. (1993). Building a Two Axes Process Model of Understanding Mathematics. Sugaku Kyoiku Gakujutsu Zasshi, 1, 63-73.

Lin, M., \& Chen, H. (2017). A Study of the Effects of Digital Learning on Learning Motivation and Learning Outcome. 8223(7), 3553-3564. https://doi.org/10.12973/eurasia.2017.00744a

McNeil, N. M., \& Alibali, M. W. (2005). Knowledge change as a function of mathematics experience: All contexts are not created equal. Journal of Cognition and Development, 6(2), 285-306. https://doi.org/10.1207/s15327647jcdo6o2_6

Midgett, C. W., \& Eddins, S. K. (2001). NCTM's Principles and Standards for School Mathematics : Implications for Administrators. 623, 35-42.

Pirie, S., \& Kieren, T. (1994). Growth in mathematical understanding: How can we characterise it and how can we represent it? Educational Studies in Mathematics, 26(2-3), 165-190. https://doi.org/10.1007/BF01273662

Powell, S. R., Driver, M. K., \& Julian, T. E. (2015). The Effect of Tutoring With Nonstandard Equations for Students With Mathematics Difficulty. Journal of Learning Disabilities, 48(5), 


\section{3-534. https://doi.org/10.1177/0022219413512613}

Powell, S. R., \& Fuchs, L. S. (2010). Contribution of Equal-Sign Instruction Beyond Word-Problem Tutoring for Third-Grade Students with Mathematics Difficulty. Journal of Educational Psychology, 102(2), 381-394. https://doi.org/10.1037/a0018447

Rittle-Johnson, B., \& Alibali, M. W. (1999). Conceptual and procedural knowledge of mathematics: Does one lead to the other? Journal of Educational Psychology, 91(1), 175-189. https://doi.org/10.1037/0022-0663.91.1.175

Sartika, \& Octafiani, M. (2019). Pemanfaatan Kahoot untuk pembelajaran matematika siswa kelas $\mathrm{X}$ pada materi sistem persamaan linear dua variabel. Journal On Education, o1(03), 373385 .

Sharples, M. (2000). The design of personal mobile technologies for lifelong learning. Computers and Education, 34(3-4), 177-193. https://doi.org/10.1016/so360-1315(99)ooo44-5

Sheftyawan, W. B., Prihandono, T., \& Lesmono, A. D. (2018). Identifikasi Miskonsepsi Siswa Menggunakan Four-tier Diagnostic Test pada Materi Optik Geometri. Jurnal Pembelajaran Fisika, 7(2), 147-153.

Sumardyono, M. P. (2012). Penggunaan pertama simbol matematika. 1-7.

Ulimaz, A., \& Agustina, D. K. (2020). Respon Mahasiswa Vokasi Terhadap Pembelajaran Dengan Kahoot Pada Materi Parameter Limbah Cair. SENASTER" Seminar Nasional Riset .... https://jurnal.untidar.ac.id/index.php/senaster/article/view/2606

Wang, A. I. (2015). The wear out effect of a game-based student response system. Computers and Education, 82, 217-227. https://doi.org/10.1016/j.compedu.2014.11.004

Wang, A. I., \& Lieberoth, A. (2016). The effect of points and audio on concentration, engagement, enjoyment, learning, motivation, and classroom dynamics using kahoot! Proceedings of the European Conference on Games-Based Learning, 2016-Janua(October), 738-746.

Wang, A. I., \& Tahir, R. (2020). The effect of using Kahoot! for learning - A literature review. $\begin{array}{llll}\text { Computers and } & 103818 .\end{array}$ https://doi.org/10.1016/j.compedu.2020.103818

Wigati, S. (2019). Penggunaan Media Game Kahoot Untuk Meningkatkan Hasil Dan Minat Belajar Matematika. AKSIOMA: Jurnal Program Studi Pendidikan Matematika, 8(3), 457-464. https://doi.org/10.24127/ajpm.v8i3.2445

Wulandari, R., Susilo, H., \& Kuswandi, D. (2017). Penggunaan multimedia interaktif bermuatan game edukasi untuk siswa sekolah dasar. Jurnal Pendidikan: Teori , Penelitian Dan Pengembangan, 2(8), 1024-1029. http://journal.um.ac.id/index.php/jptpp/article/view/9759/4611 